\title{
СТРУКТУРНО-ФУНКЦІОНАЛЬНИЙ КОНТЕКСТ ХУДОЖНЬОГО СВІТУ ТОПОСУ МІСТА У ТВОРАХ Т. ШЕВЧЕНКА: ПРОСКЦІЇ І РЕФЛЕКСІЇ УРБАНІЗМУ
}

\author{
Боклах Д. Ю.
}

\section{ВСТУП}

Семіосфера міста втілюється в певному топосі, що окреслює часопросторові координати для відтворення його географії, ландшафту в синкретичній єдності із внутрішнім світом героїв та авторською візією предметного світу. Місто являє собою предметну єдність мови форм та історії стилю, які наявні в усьому життєвому плині культури людства ${ }^{1}$. Місто - конструкція, що має околицю й пов'язана 3 певною просторовою експансією в системі «людина - місце - людина». Місто не житло людей, а психічна істота 3 настільки ж тривалим і багатим минулим, у якій ніщо раз виникле не зникає без видимого сліду, у якій початкові фази розвитку продовжують існувати поряд 3 останніми 2 . Місто, на нашу думку, уже самостійно виступає окремим простором у часі - топосом. Місто набуває рис топосу, простору 3 динамічно змінними топологічними й метричними параметрами. Характеристиками міського топосу $є$ динамічність і мінливість, хаотичність ландшафтних та архітектурних особливостей, експансія, відсутність чітко вираженої структури ${ }^{3}$.

Л. Демська-Будзуляк зазначає, що «місто досить багато привертало уваги реалістів, таких як Панас Мирний та I. Франко. Але їхнє місто це передусім «пожирач людських доль»» ${ }^{4}$. Натомість відчутно іншу репрезентацію міста бачимо в $\mathrm{T}$. Шевченка як представника «старшого» покоління реалістів. Аналіз міста в українській літературі середини XIX ст. неможливо уявити без постаті T. Шевченка.

${ }^{1}$ Шпенглер О. Закат Европы. Очерки морфологии мировой истории : в 2-х т. $/$ ред. В. Матешук. Москва : Мысль, 1998. Т. 2. С. 93.

${ }^{2}$ Фрейд 3. По ту сторону принципа наслаждения. Тотем и табу. «Я» и «Оно». Неудовлетворенность культурой. Харьков : Клуб семейного досуга, 2014. С. 157.

Туркина В. Город как «топос». Научные ведомости Белгородского государственного университета. Серия «Философия. Социология. Право». 2009. Вып. № 7. Т. 57. С. 79.

Демська-Будзуляк Л. Топос міста та літературний контекст раннього модернізму. Наукові праці Чорноморського державного університету ім. Петра Могили. Серія «Філологія». 2009. Т. 118. Вип. 105. С. 15. 
Уважаємо за необхідне доповнити це твердження дослідниці тим, що розуміння ставлення «класичного» покоління українських реалістів до міста буде неповним без М. Гоголя, Є. Гребінки, Г. КвіткиОснов'яненка, П. Куліша i, безперечно, Т. Шевченка. Топос міста стає невіддільним елементом української літератури, починаючи із середини XIX ст. Особливо інтенсивно він упроваджувався в епоху реалізму й натуралізму, коли міська культура ставала складником психології літературного героя 5 .

Говорячи про топос міста в реалістичній літературі середини XIX ст., варто виділити окремий локальний міський текст творчості T. Шевченка, адже він містить унікальні матриці відображення урбаністичного буття та міських реалій у різних часових і проблемнотематичних аспектах. Зважаючи на це, дослідження семіозису міського часопростору творів $\mathrm{T}$. Шевченка постає актуальним аспектом шевченкознавства, тому що топос міста презентує комплекс індивідуальних, особистісно-психологічних, семіотико-символічних параметрів зображення міста.

\section{1. Концептосфера часопростору міста: рецептивний аспект літературознавства}

Місто увиразнює часопросторову експансію в системі людини й цивілізації. Навколишня дійсність, ландшафт утворюють у тексті своєрідну сферу взаємопов'язаних елементів. Розглядаючи літературну урбаністику Шевченкових творів, послуговуватимемося поняттями «топос міста», «хронотоп міста», «локус міста».

Поняття «топос» започатковане із часів античності у філософії та риториці. У філософії це поняття було введене Протагором Абдерським (прибл. 480-410 рр. до н. е.) і детально розроблене Аристотелем («Топіка», «Риторика»). А. Артеменко і Я. Артеменко зазначають, що проблема топосу у філософії («Фізика» Аристотеля, «Закони» Платона) пов'язана зі сферою онтології, де поняття «топос» формується як система ознак i властивостей конкретного місця як чинника, що впливає на властивості й функційне призначення речі ${ }^{6}$ Тому, за словами М. Карповця, без розуміння генези «аристотелівського топосу місто не може існувати як реальність» ${ }^{7}$.

5 Демська-Будзуляк Л. Топос міста та літературний контекст раннього модернізму. Наукові праці Чорноморського державного університету ім. Петра Могили. Серія «Філологія». 2009. Т. 118. Вип. 105. С. 11.

${ }^{6}$ Артеменко А. Онтологія топосу. Наукові записки Національного університету «Острозька академія». Серія «Філософія». 2014. Вип. № 15. С. 84-85.

7 Карповець М. Місто як світ людського буття : монографія. Острог : Вид-во Нац. ун-ту «Острозька академія», 2014. С. 84-85. 
У літературній модифікації Е. Курціуса топос, з одного боку, позначає стійкі схеми, вислови, які поширилися в античній літературі завдяки засадам риторики, з іншого боку, топосу притаманні параметри часопросторової усеприсутності ${ }^{8}$. Така дефініція поняття залишається актуальною і в теорії літератури, хоча в літературній урбаністиці «топос» модифікується як зовнішній (відкритий) простір, необмежений функційними полями (Ю. Безхутрий, О. Боронь, А. Булгакова, I. Вихор, М. Калиняк, I. Козлик, І. Лисенко, I. Ткаченко, Н. Тодчук, В. Фоменко та ін.).

I. Вихор упевнена, що, з одного боку, топос міста відображає реальні топографічні ознаки міста, з іншого - відповідно до ідейноестетичних візій автора трансформується в картину міста як упорядкований простір 9 .

Топос міста - це предметно-атрибутивний світ відтворення природно-архітектурного ландшафту урбаністичного середовища, який стає культурно-цивілізаційним універсумом буття героїв, реалізуючись крізь домінанти локусів у часі, що мають втілення в художньому творі крізь семіотику міського тексту.

Вагомими в розпізнаванні структури міста є елементи, виокремлені iз загального змісту, що розкривають темпоральні особливості соціального життя міста й допомагають відтворити його топографію ${ }^{10}$. Такими елементами топосу можуть виступати локуси. Під локусом розуміємо будь-який уведений у художній текст автором простір, що має видимо / умовно окреслені межі території (вулиця, будинок, кімната, сад, ганок). Рецепція локусу створюється завдяки суб'єктивному баченню героєм конкретного місця в часовій ретроспекції з відсиланнями до досвіду, пам'яті.

Локальною частиною топосу міста також $є$ хронотоп, у якому простір і час згущуються, стаючи художньо зримими, а просторова структура хронотопу ніби вплітається у плин часу й історії крізь призму світу окремих локусів, зосереджених у мікроструктурі самого хронотопу, що водночас $є$ локусами міста. Локус міста означає вузьку атрибутивно-опредмечену дію в часі, а хронотоп поєднує ці локальні дії в одне структурне, просторове й смислове ціле у складі топосу міста.

8 Курціус Е. Європейська література та латинське середньовіччя. Львів : Літопис, 2007. С. 92-123.

${ }^{9}$ Вихор I. Дискурс міста в українській поезії кінця XIX - першої половини ХХ ст. : дис. ... канд. філол. наук: 10.01.06. Тернопіль, 2011. С. 66.

${ }^{10}$ Богданова О. Топографічний образ міста у прозі М. Хвильового та романі «Берлін. Александерплатц» А. Дьобліна. Вісник Львівського національного університету ім. І. Франка. Серія «Іноземна філологія». 2014. Вип. 126. Ч. 1. С. 32. 
Топос міста - психологема автора й героя, де перший існує в метафізичних глибинах часопросторових координат дійсності, a останній ретранслює суб'єктивні погляди об'єктивної дійсності. К.Г. Юнг визначає психологему як надзвичайно давню архетипічну структуру $^{11}$, яка собою створює сферу підсвідомості й чуттєвого досвіду, де внутрішній світ, психіка людини шукають опору, черпають натхнення в іманентному середовищі. Архетип i топос міста $\epsilon$ важливим структуротвірним чинником мислення автора, а смислове значення «місця» зумовлене тим, що воно $€$ активним учасником творчого процесу, існує і у творі, і поза ним ${ }^{12}$.

Часопросторові координати художньої моделі урбаністичного світу утворюють топос міста, який, виходячи з міркувань Ю. Лотмана, може бути точковим, лінеарним і об'ємним ${ }^{13}$.

Точковий топос має закриту організацію і вживається в тексті як окремий топонім без істотного розгортання стратегії локусів-психологем (дія відбувається в межах одного смислового просторового континууму). Точковий топос характерний для поезії, де автор, уживаючи певні топоніми, не вдається до деталізації їхньої структури, але вони відчутно несуть ідейно-тематичний, смисловий аспекти відтворення.

Лінеарний топос заданий у координатах розвитку подій, де герой входить у дію в певних локусах із докладним відтворенням предметноатрибутивного світу міста. Лінеарний топос містить суттєву просторову стратегію в зображенні локусів-психологем, які поєднані сюжетним лінійним ланцюгом розгортання подій.

Об'ємний топос міста визначається горизонтальною та вертикальною спрямованістю континууму одночасно, репрезентуючи міський топос як містку конструкцію в часі, на відміну від площинного часопростору, що характеризується горизонтальною або вертикальною спрямованістю й репрезентує надвеликі простори (наприклад, топос неба, топос степу, топос України, топос Землі, топос країни тощо).

\section{2. Моделі структурної організації топосу міста в поезії та ліро-епосі: специфіка організації чуттєвих інтенцій часопростору}

Семантичну модель міського поетичного топосу, на думку I. Вихор, варто розглядати в часовій локалізації його предметно-смислових ознак ${ }^{14}$, які, 3 одного боку, утворюють часопростір архітектури й цивілізації, модусів дійсності, з іншого - чуттєвий простір.

${ }^{11}$ Юнг К.Г. Душа и миф: шесть архетипов. Киев, 1996. С. 343.

12 Доній Т. Архетипи і топоси постмодерністської поезії України та США : дис. ... канд. філол. наук: 10.01.05. Київ, 2018. С. 43-44.

13 Лотман Ю. Избранные статьи : в 3-х т. Таллин : Александра, 1992. Т. 1. С. 414.

14 Вихор I. Дискурс міста в українській поезії кінця XIX - першої половини XX ст. : дис. ... канд. філол. наук: 10.01.06. Тернопіль, 2011. С. 66. 
Топос Путивля 3 переспівів Т. Шевченка «Слова о полку Ігоревім» («Плач Ярославни») відтворює епоху Київської Русі XII ст. Путивль стає містом страждання й переживання ліричної героїні Ярославни, де лінійний час згущується, тісно йдучи ыз простором, утворює точковий топос просторової одночасності подій. Путивль віддзеркалює і часові рамки подій, що сталися далеко за межами міста. Топос міста розкриває діапазон просторового континууму всієї Руської землі, яка переживає разом із Ярославною тяжкий бій русичів, а в місті видніється локус валу та брами: «І плаче, плаче Ярославна / В Путивлі на валу на брамі» ${ }^{15}$. Топосом Путивля створюється драматичний, психологічний просторовий континуум крізь переживання ліричної героїні. Тому, на думку М. Гайдеггера, психічне, душевне в найширшому сенсі, хоч $\mathrm{i}$ не маючи ознак протяжності, характеризується просторовістю, усе-таки перебуває у просторі ${ }^{16}$.

Ліро-епічна поема Т. Шевченка «Гайдамаки» репрезентує цілу палітру українських міст i малих містечок разом із козацькоселянським національно-визвольним повстанням на Правобережній Україні в 1768-1769 рр. проти гніту Речі Посполитої. Міста й містечка у творі втілюють точковий простір топосу, що має гранично обмежену організацію у просторі та вживається в тексті у вигляді окремих топонімів без істотної локалізації розміщення конкретних подій у часі. Вузловими для побудови історичного простору в поемі «Гайдамаки» $\epsilon$ численні топоніми ${ }^{17}$, тому саме вони визначають у творі історичне тло та зміну ключових подій. Чигирин - місто, де зосереджується вся козацька честь і сила українського народу. Топос міста має зв'язок із духами славних пращурів-козаків, уособлюючи сакрально-містичний сенс і народну звитягу водночас: «Кругом святого Чигрина / Сторожа стане 3 того світу, / Не дасть святого розпинать» ${ }^{18}$. Історичне заворушення показано в ракурсі народного бунту, домінантним явищем $\epsilon$ стихія вогню, що стає образом духовної енергії, відтак сприймається як деміург, який виходить із сонця, а тому він співвідноситься, з одного боку, із променем сонця і блискавкою, а 3 іншого - із золотом ${ }^{19}$ : «Горить Сміла, Смілянщина / Кров’ю підпливає. / Горить Корсунь,

${ }^{15}$ Шевченко Т. Повне зібрання творів : у 6-ти т. Київ : Наук. думка, 2003. Т. 2 : Поезія 1847-1861. С. 343.

${ }^{16}$ Хайдеггер М. Пролегомены к истории понятия времени. Томск : Водолей, 1998. C. 131.

${ }^{17}$ Боронь О. Поетика простору в творчості Тараса Шевченка : монографія. Київ : Агентство «Україна», 2005. С. 88.

${ }^{18}$ Шевченко Т. Повне зібрання творів : у 6-ти т. Київ : Наук. думка, 2003. Т. 1 : Поезія 1837-1847. С. 155.

${ }^{19}$ Кирло Х. Словарь символов. Москва : ЗАО «Центрполиграф», 2010. С. 297. 
горить Канів, / Чигирин, Черкаси; / Чорним шляхом запалало» ${ }^{20}$. Просторовий континуум поеми репрезентований емотивно й віддзеркалює історіософські погляди письменника, а часові та просторові відображення топосів деталізуються, хоча й мають точковий характер, зберігається чітка система топологічних відношень.

Архетипіка простору в поемі-містерії «Великий льох» просякнута мотивами топосів Переяслава, Батурина, Берестечка, Канева, Парижа, Москви, які несуть суттєве сюжетотворче навантаження, утворюючи точковий часопростір. Топоси міст у творі урізноманітнені мотивом свого роду «гри» у конфігураціях історії, що подаються в ракурсі вільно, відтак часопросторовий потік рецепції цих топосів ускладнюється, бо вони розташовані у тканині твору хаотично. Крізь топоси міст у поемі «Великий льох» автор створює своєрідний текст історії України, а самі міста кодують у собі глибинну інформацію націософських поглядів письменника. Топос Переяслава зосереджував головне багатство українського народу - волю, яку названо «крамом», а тому місто втілює останнє пристанище української волі, яку так необережно проміняв Б. Хмельницький на Московський патронат: «Крав Богдан крам. / Та повіз у Київ, / Та продав злодіям / Той крам, що накрав» ${ }^{21}$. Топос Берестечка постає як нагадування про криваву битву Б. Хмельницького 3 польською армією в червні 1651 р. і зраду татарського хана Іслама Гірея III. Топос Берестечка - місто втраченої надії на перемогу у визвольній боротьбі.

Поезія «Чигрине, Чигрине» ретранслює точковий топос історичного міста, де тривалий час вирішувалася доля України. Чигирин - топос минувшини, який стає свідком і персоніфікованим учасником невдалих визвольних змагань українського народу. Доля колишньої козацької столиці Б. Хмельницького в уяві Т. Шевченка асоціюється з долею всієї України. Топос Чигирина стає символом занедбаного героїчного минулого, сумних картин новітнього для автора сучасного, уособлює втрату національної волі, самостійності, яку символізують руїни міста: «Чигрине, Чигрине, / Все на світі гине, / I святая твоя слава, / Як пилина, лине» ${ }^{22}$.

У поемі «Варнак» старий дід-спокутник оповідає про «диво дивне», а святе місто Київ стає другим Єрусалимом - точковим топосом перевтілення і надії на спокуту. Місто втілює ідею християнського всепрощення крізь метафізичний простір: «Дивлюся, / Мов на небі

${ }^{20}$ Шевченко Т. Повне зібрання творів : у 6-ти т. Київ : Наук. думка, 2003. Т. 1 : Поезія 1837-1847. С. 161.

${ }^{21}$ Там само. C. 318.

22 Там само. C. 254. 
висить / Святий Київ наш великий. / Святим дивом сяють / Храми Божі, ніби з самим / Богом розмовляють» ${ }^{23}$.

На точковий топос Петербурга натрапляємо в поезіях «О люди! Люди небораки!», «Якось-то йдучи уночі», «Кума моя i я» Т. Шевченка, які презентують вузький просторовий спектр відтворення атрибутики міста. Поезія «О люди! Люди небораки!» відтворює кліматично прохолодну картину нічного Петербурга, яка зображена 3 натуралістичними подробицями. Нева уособлює локус безнадії для ліричного героя, що спостерігає подію прощання вихованців дитячих притулків 3 імператрицею Олександрою Федорівною в Петропавлівському соборі, демонструючи «скорботу народну». У центрі поезії «Якось-то йдучи уночі» - локуси Двірцевої набережної міста Нева, Зимовий палац та інші палати, що візуалізуються вночі. Ліричний герой бачить два ліхтарі Невських воріт Петропавлівської фортеці, розташованої на березі Неви, які ніби примушують його схаменутися i знову повернутися до болючих роздумів над несправедливим устроєм життя, над паразитичним способом буття царату. Ліричний герой поезії «Кума моя і я» блукає вулицями Петербурга, немов лабіринтом: «Кума моя і я / В Петрополіськім лабіринті / Блукали ми - i тьма, і тьма» ${ }^{24}$. Місто у свідомості героя утворює заплутану комбінацію ходів, де все просякнуте духовною порожнечею. Герої хочуть потрапити в «піраміду», щоби віднайти істину, повноту буття: «Ходімо, куме, в піраміду, / Засвітим світоч» ${ }^{25}$.

$\mathrm{У}$ поемі «Сон» («У всякого своя доля») Петербург проходить крізь рецепцію ліричного героя в мареві, сні. К.Г. Юнг стверджує, що аспект особисто несвідомого будь-якого явища відкривається нам у снах, у яких воно має вигляд символічного образу ${ }^{26}$. Аспект особисто несвідомого начала постає перед нами в образі завуальованого герояп'янички, який бачить у тлі сну символічну площину топосу Петербурга в різних часових ракурсах: побудова міста реєстровим козацтвом, царювання Петра I, Катерини II (локус пам'ятника Петру I), мордування гетьмана Полуботка (локус Петропавлівської фортеці), апогей деспотизму Миколи I (локуси Зимового палацу, вулиці, розпуття) та ін.

Місто для героя постає з висоти пташиного польоту, де Петербург залишається семантично незмінним із різних ракурсів - із неба та землі:

${ }^{23}$ Шевченко Т. Повне зібрання творів : у 6-ти т. Київ : Наук. думка, 2003. Т. 2 : Поезія 1847-1861. С. 76.

${ }^{24}$ там само. С. 371.

${ }^{25}$ Там само.

${ }^{26}$ Юнг К.Г. Подход к бессознательному. Человек и его символы / К.Г. Юнг и др. Санкт-Петербург : Б. С. К., 1996. С. 19. 
«У долині, мов у ямі, / На багнищі город мріє; / Над ним хмарою чорніє / Туман тяжкий» ${ }^{27}$. Семіотичний код Петербурга - прагматичний уклад локусів-психологем, які взаємодіють як мертві відбитки духовно порожнього простору: «Дивлюся: / Палати, палати / Понад тихою рікою; / А берег ушитий / Увесь каменем» ${ }^{28}$.

Домінантою Петербурга, за словами М. Анциферова, є характер його «кристалізуючого» ядра. Генеза Петербурга полягає в тому, що він будувався як місто-фортеця ${ }^{29}$. Ліричний герой чітко бачить «кристалізуюче ядро Петербурга» - палац, верхівку дзвіниці, фортецю, пам'ятник Петру I. Усі зазначені локуси Петербурга, говорячи словами Е. Гуссерля, становлять замкнену в собі єдність, яка тягнеться в нескінченну єдність універсуму природи й цивілізації, що має універсальну просторово-часову форму ${ }^{30}$. Проте така єдність тільки фізична, у творі вона позбавлена одухотвореного начала.

M. Еліаде стверджує, що профанний простір вирізняє від сакрального саме відсутність Духу ${ }^{31}$. Петербург пристосований лише як топос для життя владної верхівки за відсутності духовної сфери: «Церкви, та палати, / Та пани пузаті» ${ }^{32}$. Ліричний герой бачить справжне паразитичне процвітання панства в Зимовому палаці на тлі секуляризованої та профанної моделі буття апологетів царату. Omne malum ex urbe для ліричного героя йде 3 монструозного центру палацу імператора. Локус пам'ятника Петру I відтворено в динаміці, він втілює саркастичний ідеал правителя 3 ницими вчинками та культом вояччини, псевдодосконалості.

«Центр» Петербурга презентовано локусом дії в палаці імператора та навколишніх спорудах міста, а простір «периферії» позначено баченням життя пересічних людей у локусі міської вулиці. Топос Петербурга лінеарний, бо події розгортаються в ряді структурних локусів, та об'ємний водночас, оскільки зактуалізована опозиція зображення «верх - низ», коли герой потрапляє до міста («небо», «палац», «центр») та бачить весь спектр простору («мов у ямі», «вулиці», «периферія»). Топос окреслено в ширині (наповнення локусу

${ }^{27}$ Шевченко Т. Повне зібрання творів : у 6-ти т. Київ : Наук. думка, 2003. Т. 1 : Поезія 1837-1847. С. 271.

${ }^{28}$ Там само. С. 274.

${ }^{29}$ Анциферов Н. Пути изучения города как социального организма. Ленинград : Сеятель, 1926. С. 119.

${ }^{30}$ Гуссерль Э. Избранные работы / сост. В. Куренной. Москва : Издательский дом «Территория будущего», 2005. С. 300.

31 Элиаде М. Оккультизм, колдовство и моды в культуре. Киев : София ; Москва : ИД «Гелиос», 2002. С. 152.

${ }^{32}$ Шевченко Т. Повне зібрання творів : у 6-ти т. Київ : Наук. думка, 2003. Т. 1 : Поезія 1837-1847. С. 271. 
смислами й атрибутами), довжині (кількість локусів), висоті (опозиція «верх - низ»).

Петербурзька містерія зникає із приходом ранку. У просторі «периферії» герой бачить убогих людей, які потерпають від царського свавілля, заробляючи собі на життя: «Розлетілись, розсипались, / Сонечко вставало / Уже вбогі ворушились, / На труд поспішали» ${ }^{33}$. Опозиція «низу» у Т. Шевченка - семантично «чиста». Однак навіть сонце як символ тепла, затишку не здатне розвіяти ниций світ Петербурга, не перестають існувати його чорні діри як зловісний макрокосмос, який всмоктує у себе пересічних людей.

Поезія «У Вільні, городі преславнім» репрезентує міський текст, у якому виразно простежується історична архітектоніка відтворюваної місцевості топосу Вільно. Першу частину поезії можна назвати документально-історичною, тому початкові строфи поезії ніби «втягують» у фрагмент простору історії Литви першої половини XIX ст., який створюється за допомогою локусів Віленського університету, Острої брами. Подія розгону «бакалярів» у Т. Шевченка «За те, що шапки не ламали / У Острій брамі» ${ }^{34}$ набуває переосмислення, бо насправді їх розігнали за те, що брали участь у Листопадовому повстанні 1830-1831 pр. проти російського царату. Друга частина поезії зображає душевні переживання, внутрішній світ трагічного кохання юнака й дівчини-жидівочки у всій його суперечності. Локус міської вулиці та воріт підкреслює атмосферу жаданої зустрічі й романтики: «Тілько заходилась / <..> I вночі спустилась / До студента на улицю. / І де б утікати, / А вони - звичайне, діти - / Любо ціловатись / Коло воріт заходились» ${ }^{35}$. Локуси Вільно зберігають, 3 одного боку, суспільно-політичну ситуацію в місті 1830-1831 pp. (Віленський університет, Остра брама), а 3 іншого відтворюють психологічні колізії ліричного героя, навіяні «почуттєвою драмою» закоханих - юнака й дівчини іншого віросповідання (локуси будинку, урочища Закрет, ріки Вілії), зображуючи часову всеприсутність і семантичну навантаженість, тому топос Вільно втілює лінеарний простір. У поезії натрапляємо на поетику художнього паралелізму - драматичну синхронізацію історичних подій і трагічних обставин почуттєвої драми закоханих.

Топос Єрусалима (поема «Марія») окреслений завдяки побудові детального простору міста, що має локалізацію життя та хресного

${ }^{33}$ Шевченко Т. Повне зібрання творів : у 6-ти т. Київ : Наук. думка, 2003. Т. 1 : Поезія 1837-1847. С. 276.

${ }^{34}$ Шевченко Т. Повне зібрання творів : у 6-ти т. Київ : Наук. думка, 2003. Т. 2 : Поезія 1847-1861. С. 162.

35 Там само. С. 163. 
шляху Месії. У творі біблійні місцевості чітко впізнавані, наділені високою семіотичністю, тому й породжують інформаційно насичені зорові уявлення ${ }^{36}$. Локус синагоги презентує початок місіонерської діяльності Месії серед іудейського народу, а тому це «святе місце» Божого просвітлення для людства, сакральний всесвіт Єрусалима. Локуси яру, криниці надають рустикального відтінку міському топосу, який сповнюється атрибутами народної символіки. Натрапляємо в часопросторі на локуси гір Сіон, Єлеон та Голгофа, що стають виразниками сакрального світу міста. Автор презентує Сіон як найвищий вияв Божої благодаті. Локус гори Слеон виступає неповторним місцем концептуалізації духовного пошуку Месії. Голгофа - місце страти героя, на яке натрапляємо в авторському баченні подій без дії в часі на горі та локалізації подій: «Пішла [Марія] тинятись попідтинню, / Аж поки, поки не дійшла / Аж до Голгофи» ${ }^{37}$. Локус місця страти не має конкретної деталізації, оскільки він візуально відчутний у передвісті трагічних подій і пов'язаний з образом Діви Марії. Топос Срусалима, попри створення семіосфери есхатологічної міфологеми, позбавлений негативного зображення, але не позбавлений катастрофічних очікувань. Топос міста в поемі $\epsilon$ об'ємним і лінеарним водночас, бо герої потрапляють у життєві ситуації, а організація часопростору відзначається опозицією структурних елементів: «верх» («сакральне»: Єлеон, Сіон, Голгофа) і «низ» («профанне»: ярмарок, вулиця, яр).

\section{3. Онотологічні модуси топосу міста у прозі: своєрідність антропологічного виміру}

Особливо широке розкриття топосу міста бачимо у прозописьмі, бо «епічна форма вільна в розпорядженні часом і місцем - тут більше свободи, ніж у драмі» ${ }^{38}$.

Топос Переяслава в повісті «Близнецы» презентується крізь рецепцію міста автором-оповідачем, що детально описано, але увагу акцентовано на розташуванні міста, яке «издали кажется в тумане, но над городом из тумана выходила белая осьмиугольная башня, увенчанная готическим зеленым куполом с золотою главою» ${ }^{39}$.

36 Клочек Г. Поетика візуальності Тарса Шевченка : монографія. Київ : Академвидав, 2013. С. 208.

${ }^{37}$ Шевченко Т. Повне зібрання творів : у 6-ти т. Київ : Наук. думка, 2003. Т. 2 : Поезія 1847-1861. С. 326.

${ }^{38}$ Ауэрбах Э. Мимесис. Изображение действительности в западноевропейской литературе. Москва : Прогресс, 1976. С. 537.

${ }^{39}$ Шевченко Т. Повне зібрання творів : у 6 т. Київ : Наук. думка, 2003. Т. 4 : Повісті. С. 17. 
Водночас увагу зосереджено на історичних подіях, що відбувалися в місті та його околицях (місце вбивства безневинного князя Бориса, Тарасова ніч 1630 р. тощо) ${ }^{40}$. Детальний опис топосу Переяслава дає змогу простежити життя міста в часовому вимірі кілька століть тому 3 огляду на ландшафт, будівлі, які стають віддзеркаленням історії міста. Переяслав має сакральне значення, оскільки місто постає як пам'ятник духу народу. Завдяки змішуванню часових і просторових пластів хронотопу твору Т. Шевченко досягає наближення, унаочнення історичних епізодів минулого ${ }^{41}$, що дає змогу інтерпретувати топос Переяслава крізь рецепцію ландшафту як палімпсесту історії, який стає «місцем» розгортання «сучасного» життя для героїв твору. Переяслав відтворюється без конкретного улокування життя героїв, а радше стає простором архітектурних локусів міста (Вознесенський собор, Успенська церква й ін.), що мають семіотичне значення простору «сивої давнини» у часовому вимірі до життя сотника Сокири на хуторі поблизу міста. Герой-оповідач бачить ніби, «как алмазы, горят переяславские храмы Божии, и один из них ярче всех сверкает своею золотою головою. Это собор, воздвигнутый Мазепою» ${ }^{42}$. Ландшафтна забудова Переяслава стає мапою історії, візуалізація міста у просторі «здалеку» пов'язана із баченням рівнини, засіяної житом та історичними могилами, тому місто утворює лінеарний простір.

Комунікативний дискурс організації поетикального наративу відтворення топосу міста в повісті «Близнецы» зосереджено навколо гомодієгетичного наратора в екстрадієгетичній ситуації, який веде оповідь від першої особи та проєктує предметний і духовний семіозис Києва в лінеарному часопросторі подій.

Семіозис топосу Києва постає у проєкції «минулого» й «сучасного» для автора-оповідча. Топос міста подано в ретроспекції оповідачем подій, які безпосередньо відбувались у Києві. У центрі топосу - життя Никифора Сокири й названого сина Саватія в координатах лінеарного простору, а також візія оповідача, який ніби міметично відтворює географічну мапу Києва, апелюючи до власних ретроспективних спогадів. Однак за такою «маскою пасивності» приховано глибокі інтенції розуміння метафізики й сакрального ландшафту Києва, що свідчать про активізацію внутрішнього єства героя, яке співвідносне із Шевченковим alter ego. У повісті йдеться про навчання Никифора

${ }^{40}$ Шевченко Т. Повне зібрання творів : у 6 т. Київ : Наук. думка, 2003. Т. 4 : Повісті. С. $487-488$.

${ }^{41}$ Новик О. Історична ретроспектива в повісті Тараса Шевченка «Близнецы». Волинь - Житомирщчина. 2010. № 21. С. 131.

${ }^{42}$ Шевченко Т. Повне зібрання творів : у 6 т. Київ : Наук. думка, 2003. Т. 4 : Повісті. С. 109. 
Сокири в київській бурсі, але для героя найістотнішою стала зустріч із відомими людьми того часу: «Иваном Левандою, Григорием Гречкою и тогда уже философом Григорием Сковородою» ${ }^{43}$. Виходячи 3 міркувань Є. Андроса, проблема людського буття - це проблема співбуття людей ${ }^{44}$, яке генерує міжособистісні зв'язки городян, героя. Київ уособлює простір навчання, якісних змін, важливих зустрічей, розвитку. Григорій Гречка стає духовним наставником Никифора, провідником у багаторівневий світ знань, таїнств і складнощів життя міста, розкривши талант «голосу архангельського». Як стверджує Л. Вірт, індивід у середовищі міста досягає певної емансипації, свободи від особистого й емоційного контролю 3 боку інших ${ }^{45}$. Почуття, симпатія - невід'ємні складники індивідуального простору життя Саватія у великому місті: «В Киеве, бывало, гуляя перед вечером в саду по большой аллее, встретит он красавицу, - так холодом и обдаст его, и он, ошеломленный, долго стоял на одном месте» ${ }^{46}$. Юнацьке захоплення стає нетривалим, це лише одна зі спроб побудувати особисте життя, адже герой наприкінці своїх «інтимних роздумів» інтуїтивно впевнений, що вони 3 незнайомкою не пара. Інтуїція, на думку А. Бергсона, рухається у процесі самого життя ${ }^{47}$, але вона рушій розвитку, чуттєва спроба змін. Саватій захоплено спостерігає за панорамою вечірнього міста, він глибоко емоційно сприймає світ його локальних місць, йдучи від Хрещатика до свого помешкання; герой будує геопоетичний маршрут локусів. Помітною $\epsilon$ проблема самотності героя в тенетах великого міста, натомість це не пригнічує його, а, навпаки, актуалізує імпульс самовдосконалення й пізнання нового. Для Саватія Київ - місто самоствердження, де він реалізує свій інтелектуальний потенціал, стаючи лікарем.

Топос Києва презентує відверто комедійно-побутову дію, спроєктовану ретроспективним баченням оповідача, у локусі тогочасного контрактового ярмарку про купівлю полковником Миколою Свічкою всього шампанського вина перед початком ярмаркових святкувань. Відтворене комічне дійство на Подолі зображує світсько-розважальний бік життя мешканців Києва того часу,

${ }^{43}$ Шевченко Т. Повне зібрання творів : у 6 т. Київ : Наук. думка, 2003. Т. 4 : Повісті. С. 18.

44 Людина в есенційних та екзистенційних вимірах / відп. ред. В. Г. Табачковський. Київ : Наук. думка, 2004. С. 162.

${ }^{45}$ Вирт Л. Урбанизм как образ жизни. Москва : Strelka Press, 2018. С. 25.

${ }^{46}$ Шевченко Т. Повне зібрання творів : у 6-ти т. Київ : Наук. думка, 2003. Т. 4 : Повісті. С. 74.

${ }^{47}$ Бергсон А. Творческая эволюция. Москва : ТЕРРА - Книжный клуб ; Канонпресс-Ц, 2001. С. 259. 
показує своєрідність, оригінальність задуму старого полковника щодо проведення міських бенкетних святкувань. Тим самим автор за допомогою художнього опису міського колориту оживлює Київ, надаючи відтінку «міської метушливості», «незвичайності», створює його осередком дозвілля й торгівлі, показуючи побутовий рівень життя мешканців.

Автор-оповідач генерує своєрідні ностальгічні рефлексії у відображенні міських реалій цивілізаційно-природного світу: «Чаще всего я лелею мое старческое воображение картинами золотоглавого, садами повитого и тополями увенчанного Киева» ${ }^{48}$. Кожен суб'єкт, рефлексуючи, вибудовує світ специфічно, цей світ - досвід суб'єкта, який залежить тільки від його пізнання ${ }^{49}$. Життєвий досвід наратора повертає його до важливих місць пам'яті середовища міста, а пам'ять це річка, яка завжди тече назад (П. Коельйо), оживлюючи особистісні інтенції героя-оповідача, актуалізує квінтесенцію його буття у просторі міста. Картина пейзажної ностальгії в рецепції наратора змінюється настроєм суму й доповнюється авторською візією церковної легенди про Андрія Первозванного, який освятив місцевість території сучасного Києва. Місто, за словами Я. Поліщука, відкривається як тайнопис, як код із минулого, зашифрований літопис минувшини ${ }^{50}$. Авторські рефлексії глибоко закорінені у свідомість оповідача, а тому роздуми про Київ набувають історіософської глибини, де місто уособлює мудрість віків, навіюючи інтенції сакральної міфологеми Другого Єрусалима, тому Київ корелює 3 іконічною системою пам'ятки ${ }^{51}$. На думку Д. Лихачова, «простір - своєрідне сприйняття вічності. Час закріплюється у просторових формах» ${ }^{52}$, відтак Київ «вічне місто», місто злиття часопростору й буттєвого досвіду поколінь у гетерогенну єдність.

Наратор органічно вводить у площину топосу міста сакральний локус місцевості Києво-Печерської лаври, що для нього $є$ особливим місцем душевної рівноваги: «Кто, посещая Киево-Печерскую лавру, не отдыхал на типографском крыльце, про того можно сказать, что был в

${ }^{48}$ Шевченко Т. Повне зібрання творів : у 6-ти т. Київ : Наук. думка, 2003. Т. 4 : Повісті. С. 109.

${ }^{49}$ Новейший философский словарь / сост. и гл. науч. ред. А. Грицанов. Минск : Книжный дом, 2003. С. 429.

50 Поліщук Я. Ревізії пам'яті : літературна критика. Луцьк : ПВД «Твердиня», 2011. C. 11.

5 Левицький В. Наснага та моторошність «іного краю»: урбанізм у літературних творах Тараса Шевченка. Слово $і$ час. 2015. № 3. С. 33.

52 Лихачев Д. Поэтика древнерусской литературы. Москва : Наука, 1979. С. 279. 
Киеве и не видал киевской колокольни» ${ }^{53}$. Крізь локус лаври Київ символізує місто, де реалізується духовність людини й де людина здатна посередництвом вдавання до «святых воспоминаний» найбільшим чином явити свою велич $\mathrm{i}$ свою самобутність ${ }^{54}$. Типографський ганок відкриває мальовничий краєвид на Київ та Задніпров'я, а дзвіниця - атрибут божественного Духу міста, пройнятий естетизмом архітектури, тому для оповідача це важливий елемент у зображенні координат індивідуального простору буття.

Людина в топосі - найвища форма й вимір осмислення географічних об'єктів часопростору, крізь які протікають онтологічні й екзистенційні проєкції життя. Топос Києва стає ідилічним містом людського буття, культури, архітектури, естетики й величі духу площинного топосу України, який закодовано в метафізичних глибинах художньої унікальності твору.

Відтворюючи художню матрицю топосу Петербурга в повісті «Музыкант», Т. Шевченко використовує прийом листа, у якому й зображено столицю імперії крізь призму безпосереднього бачення атрибутики головним героєм. Цей художній прийом дає змогу досягти всебічності, цілісності та об'єктивності у відтворенні часопростору міста. На думку С. Гетьман, у повісті «Музыкант» художній час нерозривно пов'язаний із простором ${ }^{55}$, i тому саме завдяки цій бінарній єдності утворюється лінеарний топос Петербурга.

Петербург відразу конструюється на початку як місто «втрати» здоров'я, рівноваги крізь локус Петропавлівської лікарні, оскільки музика Тарас, приїхавши до столиці, раптово занедужує. Оживлює картину простору лікарні природний локус саду, що уособлює місце відпочинку людини, іiі єдності зі стихією природи. Простір саду розширює образ лавки, що символізує місце зустрічі Тараса Федоровича $з$ акторкою Тарасевич. Петербург для Марії Тарасевич місто реалізації таланту, творчої атмосфери. Однак не судилося молодій і щирій людині побудувати особисте життя у просторі міста. Нахабний пан звабив акторку, вона занедужала на гарячку після невдалих пологів і була покинута в лікарні під ім'ям кріпосної дівки як відчужена особистість. Вставна історія життя акторки Тарасевич показує злиденне й нещасливе життя в Петербурзі, розширюючи

${ }^{53}$ Шевченко Т. Повне зібрання творів : у 6-ти т. Київ : Наук. думка, 2003. Т. 4 : Повісті. С. 110.

54 Задорожна Л. Історія літератури в критичних студіях М. Максимовича. «Я син свого народу». Наукова спадщина Михайла Максимовича (до 200-річчя з дня народження вченого). Київ : Просвіта, 2006. С. 53.

55 Гетьман С. Просвітницький ідеал людини та його образна інтерпретація у повістях Т. Шевченка : автореф. дис. ... канд. філол. наук: 10.01.01. Київ, 2003. С. 14. 
смисловий і проблематичний горизонт топосу міста. Бажання реалізації можливостей у столичному топосі затьмарило відчуття реальності, тому дівчина стає жертвою і заручником жорстокого середовища міста. Локус Смоленського цвинтаря стає останнім пристановищем долі акторки: «И мы вынесли ее на Смоленское кладбище. А после панихиды пропели «Со святыми упокой» да бросили земли по горсти в ее вечное жилище» ${ }^{56}$.

Музикант-кріпак переймається думками про можливі якісні зміни в його житті, які пов'язані з містом, але ці очікування не справдились: «В числе квартета и я был назначен. Радость мою только вы можете понять. Я думал: вот когда настал конец моим страданиям. А страдания только что начинались» ${ }^{57}$. Тарас - романтичний герой-мрійник, у свідомості якого місто означає нові якісні перетворення долі. Саме мрійливість формує споглядальну спрямованість характеру та допомагає розвитку внутрішнього світу людини ${ }^{58}$. Попри мрійливість, герой не втрачає реального розуміння складнощів столичного життя. Тарас організовує музичні виступи в німецькому трактирі Петербурга на Крестовському острові: «Мы стали получать заказы через содержателя трактира на вечеринки, на свадьбы» ${ }^{59}$. Місто дає можливість для розвитку талановитої молоді в соціально-побутовому просторі буття. Герой як творча особистість вільний душею у предметному світі міста, але без повної свободи, бо залишається кріпаком. Трактир - локус розваг, профанний модус взаємодії людини i міста. Музикант ніби виборює право за місце «під сонцем» у столичній атмосфері - це яскрава реалізація своєрідного екзистенціалу виживання. Мрійливість героя сприяє виживанню й адаптації до умов навколишнього середовища ${ }^{60}$.

Простір міста креслить для героя перспективи, можливості долучитися до культурних надбань сучасності. Тарас у захваті від ораторії Гайдна «Створення світу», майстерно виконаної в локусі Великого театру, що стає головним локусом культурологічного життя столичного топосу. Досить активна й талановита особистість піднімається до вершин духовної культури через залучення високого

${ }^{56}$ Шевченко Т. Повне зібрання творів : у 6-ти т. Київ : Наук. думка, 2003. Т. 3 : Драматичні твори. Повісті. С. 217.

${ }^{57}$ Там само. С. 211.

58 Чхеайло А. Потенціал виживання людини в умовах песимістичних перспектив. Грані. 2012. № 1. С. 59.

${ }^{59}$ Шевченко Т. Повне зібрання творів : у 6-ти т. Київ : Наук. думка, 2003. Т. 3 : Драматичні твори. Повісті. С. 218.

60 Чхеайло А. Потенціал виживання людини в умовах песимістичних перспектив. Грані. 2012. № 1. С. 59. 
інтелектуального потенціалу, напруження творчих сил ${ }^{61}$. Тарас стає увиразником світського способу буття завдяки своєму таланту й відкритості до пізнання нового, він долучається до розуміння сутнісних і високих ідей музичного мистецтва, але водночас він знаходить час для релігії і повноти духовного буття: «В воскресенье был я на соборном проклятии в Казанском соборе» ${ }^{62}$. Храм, собор - це локус зустрічі людини й божества, символ світобудови. Саме у храмі людина відновлює свій божественний образ крізь долучення до Христа ${ }^{63}$. Відвідування собору свідчить про глибоку духовність героя, зв'язок із народною християнською мораллю, яка не дає розчинитись у веселощах столичної богеми.

Герой-музикант подорожує Александрійським і Михайлівським театрами, мандрує Невським проспектом. Улюблене «заняття» Тараса у вільний час - читання афіш розкладу мистецьких заходів у місті. Шевченків музикант - герой-мандрівник, своїм перебуванням у локусах міста він креслить своєрідний маршрут дозвілля, сутнісну схему для розуміння культурософської географії Петербурга.

Автор конструює лінеарний топос Петербурга крізь семантичні локуси у двох проблематичних моделях: по-перше, як топос безнадії, зневіри, хвороби та втрати життєвих перспектив; по-друге, як місто прогресивного осередку культури й мистецтва, яке сприяє розвиткові талановитої молоді. Модель соціально-побутового топосу позначена негативними інтенціями, оскільки місто виступає пожирачем долі талановитої людини, це топос, уражений прогресуючою деструкцією пошуку правди й реалізації можливостей. Модель Петербурга як неповторного осередку життя в урбаністичному середовищі реалізовано крізь чуттєву рецепцію музикантом атрибутики й успішну реалізацію своїх запитів і потреб. Відтворення локусів міста зводиться до фізіологічного нарису, де ключовим елементом виступає паспортизація зображуваної урбаністичної дійсності крізь модус імпліцитного епістолярного реципієнта.

Аналізуючи повість «Художник», помічаємо, що увагу автора сконцентровано на побудові топосу міста із чітко упізнаваними локусами. Т. Шевченко конструює «міський текст» як знакову систему. Літній сад, Ермітаж, Академія мистецтв, кав’ярня мадам Юргенс,

${ }^{61}$ Ярошевич I. Концепція творчої особистості в повістях Т. Шевченка. Науковий вісник Ужгородського університету. Серія "Філологія. Соціальні комунікації». 2014. Вип. 1. С. 296.

${ }^{62}$ Шевченко Т. Повне зібрання творів : у 6-ти т. Київ : Наук. думка, 2003. Т. 3 : Драматичні твори. Повісті. С. 218.

63 Энциклопедия символов, знаков, эмблем. Москва : Эксмо ; Санкт-Петербург : Мидгард, 2007. С. 546-547. 
Великий театр - локуси, що виступають конкретними ретрансляторами життя в місті. Споруди культури як своєрідне «кристалізуюче ядро», за твердженням А. Яффе, стають символами психологічної рівноваги людини в місті, справляючи духовний вплив ${ }^{64}$.

Характерною рисою епічного топосу Петербурга стає амбівалентність, що визначає організацію простору міста за допомогою опозиції «центр культури, можливостей» - «осередок злиднів». Перша частина твору презентує більшою мірою успішне життя юного художника, натомість друга половина твору позначена негативними інтенціями, де місто перетворюється на руйнівника людської долі. Авторові вдається детально паспортизувати локальні елементи міського середовища для того, щоби досягти максимального вираження свого унікального неповторного буття в місті крізь призму художнього відтворення топосу Петербурга. Слушними щодо цього $\epsilon$ слова I. Дзюби про те, що над повістями письменника - справжній ореол Шевченкової особистості як людини й митця, що допомагає нам побачити духовні й творчі обшири автора ${ }^{65}$. Локуси міста, за словами М. Бердяєва, уміщують «цілий світ» життя суб'єкта як мікрокосму ${ }^{66}$.

Локус квартири у творі стає замкненим простором інтимноприватного життя героїв. Молодий художник страшенно боявся самотності в домашньому просторі, і тільки Академія мистецтв справляла іншу емотивну інспірацію. Локус квартири відображає й деталізує побутові подробиці, які занурені в культурологічну рецепцію приватного мікросвіту життя героїв. Так, після похорону Демського юний художник відвідує квартиру померлого, де ознайомлюється із його бібліотекою. Бібліотека як просторовий образ розширює межі узвичаєного приватного мікросвіту маркерами культурологічної сфери. Помітним стає мотив закоханості героя-художника у свою ученицю Пашу в ракурсі петербурзької квартири. Дія в темпоральному вимірі презентована навчанням учениці та змалюванням іiі як натурниці в образі весталки.

Локус-хронотоп Академії визначає часовий період знайомства юного героя з художниками, а просторовий період пов'язаний з іншими локусами Петербурга (Великий театр, Літній сад, майстерня

64 Яффе. А. Символы в изобразительном искусстве. Человек и его символь / К.Г. Юнг и др. Санкт-Петербург : Б. С. К., 1996. С. 318.

${ }_{65}$ Дзюба I. 3 криниці літ: у 3-х т. Київ: Вид. дім «Києво-Могилянська академія», 2006-2007. Т. 3 : Літературні портрети ; Дніпровський меридіан ; Зі спогадів. 2007. C. 57.

66 Бердяев Н. Самопознание (опыт философской автобиографии). Москва : Книга, 1991. С. 14. 
К. Брюллова, петербурзька квартира, кав'ярня й ін.) ${ }^{67}$. Академія мистецтв стає простором, де реалізується талант і здійснюється заповітне бажання у просторі Петербурга - отримання звання «некласний (вільний) художник» :«Так или почти так совершился этот душу потрясающий экзамен» ${ }^{68}$. Юнацька меланхолія від такої події просто зникає у героя, який нещодавно дискомфортно себе почував у місті. Стан радості й цілковитої свободи в діях панує в його душі, бо попереду - перспектива творчої роботи.

Простір топосу Петербурга постає культурологічним відбитком місць-локусів, що генерують естетичне враження реципієнта тексту й героїв твору. Оповідач захоплюється відвідинами культурних місць Петербурга, зокрема локусом Ермітажу: «Нередко случалось мне бывать в Эрмитаже вместе с Брюлловым. Это были блестящие лекции теории живописи» ${ }^{69}$.

Локус Великого театру презентує собою низку зорово-слухових образів відтворення місця дії: «Сияющий зал быстро наполнялся замаскированной публикой, музыка гремела, и в шуме общего говора визжали маленькие капуцины» ${ }^{70}$. Локус дії в театрі накладає відбиток на концепцію відтворення топосу Петербурга загалом: місто («театр дії», «маскарад») - це осяжний простір буттєвого світу, де акторами виступають герої.

Попри неоднозначну рецепцію міста героєм-оповідчем на початку твору, топос Петербурга відтворений крізь «теплі» відтінки зображення локусу Троїцького містка: «Любил я также летом встречать восход солнца на Троицком мосту. Чудная, величественная картина!» ${ }^{71}$. Місток - межовий локус, який символізує зв'язок між двома світами; відтворює те, що може бути досягнено, перебуваючи поза сферою досягнення. Місток завжди $є$ символом переходу 3 одного стану в інший, а також $\epsilon$ символом певних змін або бажання до змін ${ }^{72}$. Він стає втіленням особистісного буття людини, крізь яке семіотично втілюється життєва перспектива героя-оповідача - шлях до мистецького зростання, розкриття здібностей, що згодом переросли у справжній талант майстра, вихованого класичною урбаністичною культурою.

67 Барабаш Ю. «Коли забуду тебе, Єрусалиме...». Гоголь і Шевченко. Порівняльно-типологічні студії. Харків : Акта, 2001. С. 306.

${ }^{68}$ Шевченко Т. Повне зібрання творів : у 6-ти т. Київ : Наук. думка, 2003. Т. 4 : Повісті. С. 177.

${ }^{69}$ Там само. C. 129.

70 Там само С. 161.

${ }^{71}$ Там само. С. 121.

${ }^{72}$ Кирло Х. Словарь символов. Москва : ЗАО «Центрполиграф», 2010. С. 277-278. 
Локус Літнього саду концептуалізує взаємозв'язок юного героя із містом, що виринає у пам'яті як «приємне місце». "Locus amoenus" - це просторове зображення куточків природи для окреслення неповторного внутрішнього емоційного стану персонажа - душевної рівноваги ${ }^{73}$. Справжнім "locus amoenus" виступає Літній сад, оскільки тут відбулося доленосне знайомство юного героя 3 оповідачем, що стало вирішальним чинником подальшого життя. Сад - це локус, що втілює свідоме начало й протиставлений лісу, який уособлює несвідоме начало. Сад є сценою дії «з'єднання» чогось ${ }^{74}$. «Свідоме начало» семіотичний код початку прогресивних змін у житті героя, а «сцена дії»- аспект доленосної зустрічі юного героя й оповідача у просторовому ракурсі саду, саме сад є місцем з'єднання життєвих доль.

Естетика природного світу міста охоплює єство оповідача, йому особливо подобалось, «когда Нева спокойна и, как гигантское зеркало, отражает в себе со всеми подробностями величественный портик Румянцевского музея, угол сената и красные занавеси в доме графини Лаваль» ${ }^{75}$. Порівняння Неви із дзеркалом не $\epsilon$ випадковим художнім прийомом автора. Сферична поверхня ріки як дзеркала трансформує всі міські атрибути в неповторне ціле, що загострює увагу на специфіці відображення. Стає очевидним, що будь-яке відображення - одночасно і зрушення, загострює деякі аспекти об'єкта (ріки), з одного боку, а 3 іншого ж - виявляе структурну природу мови, у простір якої проєктується об'єкт ${ }^{76}$. Локус Неви стає точкою зрушення простору міста (динамічний аспект), водночас загострюючи естетичний аспект рецепції самого топосу Петербурга (текстова стратегія).

Петербурзький текст у творі, що реалізує локуси-психологеми, за В. Топоровим, має неповторний характер (інтенсивний аспект) ${ }^{77}$, однак ця думка не відповідає тезі Ю. Лотмана про те, що Петербург $є$ ексцентричним містом, тобто таким, що розташоване на маргінесах культурного універсуму, символізуючи місто перемоги людського розуму над стихіями ${ }^{78}$. Натомість спостерігаємо Петербург крізь різко неповторний аспект відображення його атрибутики, а тому

73 Курціус Е. Європейська література та латинське середньовіччя. Львів : Літопис, 2007. С. 220-225.

${ }_{75}^{74}$ Кирло Х. Словарь символов. Москва : ЗАО «Центрполиграф», 2010. С. 378.

${ }^{75}$ Шевченко Т. Повне зібрання творів : у 6-ти т. Київ : Наук. думка, 2003. Т. 4 : Повісті. С. 121.

${ }_{77}^{76}$ Лотман Ю. Семиосфера. Санкт-Петербург : Искусство - СПБ, 2000. С. 196.

77 Топоров В. Миф. Ритуал. Символ. Образ: исследования в области мифопоэтического. Москва, 1995. С. 280.

C. 321-322.

8 Лотман Ю. Семиосфера. Санкт-Петербург : Искусство - СПБ, 2000. 
ексцентричні модуси стирають свої межі на користь концентричних інтенцій.

У повісті «Художник» бачимо динаміку географічного простору, а тому, за словами Г.В.Ф. Гегеля, цілком закономірно, що будь-який рух поділяється на простір i час ${ }^{79}$, a сам простір тоді можливий за наявністю «духу», у нашому випадку інтенційного «я» автора та героїв твору, тоді як «час» - це відтворення автобіографічної канви життя Т. Шевченка в 1838-1842 pр. Герої твору створюють простір топосу Петербурга в лінеарній динаміці: вони інтуїтивно означають маршрути свого буття в місті.

Топоси Києва та Козельця в повісті «Княгиня», за словами Н. Копистянської, створюються завдяки уяві реципієнта ${ }^{80}$. Київ у творі моделюється у фрагментарному баченні автором-оповідачем міських реалій крізь ретроспекцію як місто, де герої перебувають у справах, як місто, звідки герої приїздять додому, подорожуючи Україною: «Бывало, покойный Катеринич приедет к нам из Киева» ${ }^{81}$. Саме в Києві на контрактовому ярмарку, що на Подолі, юній княжні Катерині Дем'янівні куплено фортепіано господарем Степановичем: «Купили и фортепьяны на контрактах» ${ }^{82}$. Віддалений топос Києва в уяві героя-оповідача уособлює місто освіти, грамоти: «В эту-то почти счастливую для меня эпоху случилось переобразование школе: прислали к нам из самого Киева стихарного дьячка» ${ }^{83}$. У розповіді старого господаря Степановича зринає топос Києва як міста спокути гріха крізь тло сповіді розбійника у ченця в локусі київського монастиря (натрапляємо на відомий переказ фольклорної легенди про «великого грішника», наприклад, цю проблему порушено в ліро-епічній поемі «Варнак»).

Містечко Козелець має в тексті твору фрагментарну реалізацію, уособлюючи місто як паспортизований топос-спогад міських реалій, атрибутів, історичних подій тощо. Зауважимо, що, попри фрагментарність, брак міських реалій, достатньою видається інтерпретація лінеарного топосу міста крізь локуси та малий просторовий образ. За твердженням Ж. Женетта, виражений просторовий характер літературного письма можна вважати символом

${ }^{79}$ Гегель Г.В.Ф. Феноменология духа. Москва : Наука, 2000. С. 83.

${ }^{80}$ Копистянська Н. Час і простір у мистецтві слова : монографія. Львів : ПАІС, 2012. C. 47.

${ }^{81}$ Шевченко Т. Повне зібрання творів : у 6-ти т. Київ : Наук. думка, 2003. Т. 3 : Драматичні твори. Повісті. С. 162.

${ }^{82}$ Там само. С. 163.

${ }^{83}$ Там само. С. 155. 
глибинної просторовості мови ${ }^{84}$, що уможливлює широку інтерпретацію топосу міста, який перебуває у площині тексту. Думка автора-оповідача повісті зосереджується на історичних реаліях, 3 якими пов'язаний топос Козельця: «Разве только что в 16[63] году здесь была собрана знаменитая Черная рада» ${ }^{85}$. Місто уособлює топос історії, де відбулася доленосна подія, яка визначила вектор розвитку Української держави. Побічно оповідач звертає увагу на локуси містечка: трактир пана Тихоновича, собор Різдва Богородиці (1752-1764 pp.), побудований в архітектурному стилі бароко растреллівської мистецької школи. Увиразником локусу собору є меморіальна мармурова дошка 3 надписом, що стає своєрідним просторовим екфразисом: «Сей храм соорудила графиня Наталия Разумовская в 1742 году» ${ }^{86}$. Топос Козельця означений дією у просторі міста, герой-оповідач «нанял <..> пару немудрых лошадок вместе с рыжим жидком» ${ }^{87}$. Відтак місто подано не тільки як паспортизований відбиток подій у ретроспекції історичного часу, а й у зображенні певної дії, до якої причетний сам автор-оповідач. Важливим аспектом відтворення художнього топосу Козельця в поемі «Княгиня» є поєднання побутових, сакральних та історичних начал, які тісно співіснують і доповнюють одне одного, утворюючи близький спрямований простір і дію в часі героя-оповідача.

\section{4. Художні параметри світу замкненого топосу міста:} ракурс конфлікту світоглядних просторів буття

У повісті «Близнецы» із листів названим батькам стає відомо про перебування Саватія Сокири в Орській фортеці.

Закритий (замкнений) простір - це локус, частина природноархітектурного універсуму, але Шевченкова Орська фортеця - це замкнений унікальний часопростір, а відтак - це окремий лінеарний топос своєрідного «залізного» міста, що протистоїть культурному універсуму буття й містить локальну архітектоніку. Відкритий/закритий - опозиція, яка характеризує сприйняття простору й визначає низку правил побутової та ритуальної поведінки ${ }^{88}$. На думку Ю. Лотмана, «закритий простір може інтерпретуватися як «печера»,

${ }^{84}$ Женетт Ж. Фигуры : в 2-х т. Москва : Изд-во им. Сабашниковых, 1998. Т. 1. C. 280 .

${ }^{85}$ Шевченко Т. Повне зібрання творів : у 6-ти т. Київ : Наук. думка, 2003. Т. 3 : Драматичні твори. Повісті. С. 157.

${ }^{86}$ Там само.

${ }^{87}$ Там само.

88 Славянские древности : этнолингвистический словарь : в 5-ти т. Москва : Международные отношения, 2004. Т. 3 : К - П. С. 594. 
«могила»» ${ }^{89}$. Засловами Д. Лихачова, письменник у творі створює певний глобальний простір, який може звужуватися до тісних меж однієї кімнати ${ }^{90}$. Тому простір фортеці конструюється Т. Шевченком як детальний конструкт атрибутів і дії в часі.

Саватій на початку рецепції ландшафту оренбурзьких степів і гір бачить одноманітний простір, позбавлений чуттєвості й антропоцентризму: «Поднявшись на горы, открылась плоская однообразная пустыня» ${ }^{91}$. Із цього моменту життя Саватія в часовій ретроспекції уповільнюється і стає психологічно нестерпним, оскільки краєвид ніби примушує душу героя страждати. Деталізація топосу міста-фортеці дає змогу побачити конкретні локуси: «Белое пятнышко - это была небольшая каменная церковь на горе, а красно-бурая лента это были крыши казенных зданий, как-то: казарм, цейхгаузов» ${ }^{92}$. Локус церкви на горі - чи не єдиний натяк на присутню духовність у цьому замкненому просторі, червоно-бура стрічка ніби береже й утримує в собі холодний простір топосу фортеці. Пейзажно-ландшафтний світ зображуваної місцевості тепер починає впливати на самого героя гнітюче негативно: «Неужели так сильно действует декорация на воображение наше? Выходит, что так» ${ }^{93}$. Саватій окреслює атрибутивне тло міста-фортеці, паспортизуючи пейзаж без яскраво вираженої емоційної конотації: «обширная площадь, окруженная с трех сторон каналом аршина в три шириною да валом с соразмерною вышиною, а с четвертой стороны - Уралом. Вот вам и крепость. Недаром ее киргизы называют Яманкала» ${ }^{94}$. Лише одне здивувало 3 цієї картини героя - постать ніби такої знайомої людини. Сцена «нечіткої» зустрічі переростає у психологічні рефлексії щодо долі брата Зосима. Саватій цілу ніч міркує про долю брата, відтак це простір роздумів у часі. Саме звідси починається «пошук правди» в замкненому просторі фортеці крізь різноманітні локуси, які репрезентуються в часовому вимірі. На думку Д. Лихачова, «простір у словесному мистецтві безпосередньо пов'язаний 3 художнім часом. Він динамічний. Він створює середовище для руху, і він сам змінюється, рухається. Цей рух (у русі з'єднується простір і час) може бути легким або важким, швидким або повільним, він може бути пов'язаний з відомим опором

89 Лотман Ю. Семиосфера. Санкт-Петербург : Искусство - СПБ, 2000. С. 283.

90 Лихачев Д. Поэтика древнерусской литературы. Москва : Наука, 1979. С. 335.

${ }^{91}$ Шевченко Т. Повне зібрання творів : у 6-ти т. Київ : Наук. думка, 2003. Т. 4 : Повісті. С. 89.

${ }_{92}$ Там само. С. 90.

93 Там само.

94 Там само. 
середовища і 3 причинно-наслідковими відношеннями» ${ }^{95}$. Таким опором середовища $€$ замкнений простір фортеці як некультурний універсум буття людини.

Намагаючись перевірити свої страшні здогадки, Саватій удається до пошуків свого «ніби брата» у фортеці. Першою зупинкою стає канцелярія - локус, місце, де сходиться весь документообіг фортеці: «В канцелярии у писаря спросил я, нет ли в их баталионе недавно присланного рядового Зосима Сокирина» ${ }^{96}$. Проте цей локус одразу переадресовує події до казарми: «услужливый писарь привел меня в казармы» ${ }^{97}$. Казарми часів життя Т. Шевченка відзначалися буденною тіснотою, тому з натуралістичними подробицями Саватій у листі до названих батьків не зображує «нечистоты и смрада, возмущающих душу и вечно сущих во всех казармах» ${ }^{98}$. Простір локусу казарми стає замкненим простором заборон $\mathrm{i}$ нечистот, тому приміщення трансформовано в ракурсі пекельного зла, гріха. Далі відбувається доленосна зустріч обох братів у «кімнаті» казарми. Зустріч і справді глибоко здивувала Саватія: «На нарах в толстой грязной рубахе сидел Зося и, положа голову на колени, как титан Флаксмана, пел какую-то солдатскую нескромную песню» ${ }^{99}$. Саватій не був готовий до такої холодної зустрічі й духовно порожньої атрибутики побаченого житла, але найбільше, що його лякало, була байдужість брата-близнюка щодо зустрічі. Зосим у замкненому просторі муштри стає злочинцем: «Придя на квартиру, я посмотрел свой бумажник и, не находя 10 рублей, убедился, что это действительно Зося. Боже мой! Что же тебя так страшно превратило?» ${ }^{100}$. Саме у відтворюваному локусі житла людська особистість Зосима зазнає трансформації у свідомості брата, який остаточно розуміє, що Зосим стає іншою особистістю. Замкнений простір знецінює людську особистість, гнітюче впливаючи на неї. Психологізм сприйняття цього простору загострюється у Саватія, який звик до відкритого простору - простору, що дає шлях вибору.

Відтворювання топосу Орської фортеці відбувається в часовій ретроспекції минулого крізь епістолярій. Як слушно стверджує Д. Лихачов, «минуле, зображене в реалістичному творі, отримує власне існування, може розвиватися всередині себе» ${ }^{101}$. Топос Орської фортеці

95 Лихачев Д. Поэтика древнерусской литературы. Москва : Наука, 1979. С. 335.

${ }^{96}$ Шевченко Т. Повне зібрання творів : у 6-ти т. Київ : Наук. думка, 2003. Т. 4 : Повісті. С. 91.

97 Там само.

98 Там само.

99 Там само.

${ }^{100}$ Там само. С. 91-92.

101 Лихачев Д. Поэтика древнерусской литературы. Москва : Наука, 1979. С. 334. 
цікавить Т. Шевченка як реальність, простір пустоти й духовно спустошеної атрибутики. У реалістичному просторі Шевченкового топосу помітне бінарне поєднання психологічного простору (простору переживання) із простором предметно-атрибутивним, який замкнений щодо Саватія і світу загалом, але відкритий для Зосима. Тут водночас спостерігаємо конфлікт ціннісних орієнтацій, які втілюють герої, i конфлікт просторів, що стає конфліктом несумірних свобод окремих особистостей.

\section{5. Ідейно-смислове поле урбаністичного хронотопу: предметний і емотивний зміст наповнення часопростору}

Розгляд координат локального простору міста як певного світу життя героїв грунтується на концептуальному моделюванні «часу» й «місця» дії. Основний часопростір повісті «Художник» - топос Петербурга - часовий проміжок життя юного героя, що протікає в зовнішньому (простір Петербурга) і внутрішньому (простір Академії мистецтв й інші локуси міста) аспектах.

Використовуючи методологію хронотопного аналізу П. Торопа, виокремлення та розгляд часово-просторових координат Петербурзької академії мистецтв передбачає дослідження трьох співіснуючих часопросторів: 1) топографічного; 2) психологічного; 3) метафізичного ${ }^{102}$.

Топографічний хронотоп є хронотопом сюжету, він поділяє твір на ряд просторово-часових одиниць, які відповідають сюжетним лініям ${ }^{103}$, тому, на думку М. Бахтіна, хронотопам «належить основне сюжетоутворювальне значення» ${ }^{104}$. Час набуває у хронотопі чуттєвонаочного характеру, а сюжетні події в ньому «конкретизуються, обростають плоттю, наповнюються кров'ю» ${ }^{105}$, стаючи зримими. Особливістю сюжету повісті «Художник» $\epsilon$ зображення періоду становлення особистого життя й мистецьких здібностей юного майстра пензля крізь призму хронотопу Академії мистецтв. Топографічний часопростір Академії створюється за допомогою дії в реальних локусах (майстерня К. Брюллова, клас малювання), а також за допомогою атрибутики міста, дотичної «близькому» простору навчального закладу (набережна Неви, сфінкси, академічні ворота). Час на цій ділянці

102 Тороп П. Тотальний переклад. Вінниця : Нова Книга, 2015. С. 33.

${ }^{103}$ Тороп П. Хронотоп. Словарь терминологии тартуско-московской семиотической школьы. URL: http://diction.chat.ru/xronotop.html (дата звернення: 15.04.2020).

104 Бахтин М. Вопросы литературы и эстетики. Москва : Художественная литература, 1975. С. 398.

105 Там само. 
простору і твору загалом - конкретно-історичний, бо зображується відома епоха кінця 30-40-х рр. XIX ст. і реальні події мистецького життя Петербурга в локальному континуумі Академії (діяльність К. Брюллова, О. Венеціанова). Відтворена дія в Академії мистецтв, зосереджена в минулому часі, виринає у спогадах героя-оповідача й епістолярії юного художника. Тому в Т. Шевченка як реаліста часові відрізки заповнені розмаїтим змістом - психологічно-віковим, сезоннокалендарним, біографічно-особистим, автор послуговується настановою секулярного сприйняття часоплину та його семантизації в координатах життєздійснення приватної особи ${ }^{106}$.

Семантично навантаженим і темпорально містким середовищем хронотопу Академії можна вважати локус кабінету-майстерні К. Брюллова як місце неповторної творчої атмосфери, де навіть предмети побуту мають означення настроєвості: «В мастерской застали мы Липина. Он принес с свежими красками палитру и, усевшись в спокойные кресла, любовался <..> подмалевком портрета <..> Жуковского» ${ }^{107}$. Особливістю топографічного хронотопу Академії мистецтв $\epsilon$ злиття повсякденних $\mathrm{i}$ різних незліченних предметів, деталей побуту зі свідомістю героїв. Усе мистецьке життя герояхудожника підкорене єдиній меті - бути в центрі уваги діяльності К. Брюллова: «После долгих и страшных испытаний забыл он все: и искусство, духовную жизнь свою, и любовь, отравившую его, и меня $<\ldots>$, но красная декорация и Карл Павлович было его последним словом» ${ }^{108}$.

Особистий простір - це локус, у якому здійснюється ідеал буття людини. Невіддільним елементом топографічного часопростору Академії для юного художника $\epsilon$ копітка робота в мистецьких класах, де герой пізнає таїни майстерності пензля, але не відмежовується від суто «теоретичної» діяльності: «В продолжение лета постоянно занимался в классах и рано по утрам ходил с Йохимом на Смоленское кладбище лопухи и деревья рисовать» ${ }^{109}$. Клас мистецтв - простір творчої атмосфери, що відмежовує героя від побутових проблем, бо це простір чистого мистецтва й експериментаторства.

Психологічний хронотоп реалізується крізь суб'єктивний світ душі й свідомості автора-оповідача та юного художника. Саме Академія мистецтв і стала тим життєвим середовищем, що зумовлює душевні

106 Кодак М. Авторська свідомість і класична поетика. Київ: ПЦ «Фоліант», 2006. C. 49.

${ }^{107}$ Шевченко Т. Повне зібрання творів : у 6-ти т. Київ : Наук. думка, 2003. Т. 4 Повісті. С. 141.

108 Там само. С. 132.

109 Там само. С. 165. 
переживання персонажів у межах інтелектуального локусу. У місті 3'являється відчуття самотності, незрозумілої меланхолії, коли все «что-то не так, все чего-то недостает для $<\ldots>$ радости» ${ }^{110}$. Натомість цей «неспокій душі» зникає тоді, коли оповідач «пошел в Академию, зашел к Карлу Павловичу» ${ }^{111}$. Момент очікування результату про реалізацію творчого проєкту героя-художника пов'язаний із відчутним емотивним переживанням. Хронотоп Академії стає простором невизначеності, можливої страхітливої невдачі, який актуалізується крізь просторовий образ «грізних» академічних воріт. Простір переживання - це трансцендентний вихід за межі особистого «Я» ${ }^{112}{ }_{3}$ огляду на навколишню атрибутику невизначеності. Тріумф усього життя для героя-художника в Петербурзі й Академії - бажана реалізація творчого мистецького проєкту: «Ужасная минута близилась. Андрей Иванович < ..> шепнул мне: «Поздравляю». Я в жизнь свою не слыхал и не услышу такого сладкого, такого гармонического звука» ${ }^{113}$. Звук, почутий у стінах Академії, наблизив героя до екзистенції здійснення заповітної мрії.

Хронотоп Академії мистецтв стає системою простору онтології 3 окремою культурою та ціннісними орієнтаціями, які відрізнялися від «примарної» генези цінностей Петербурга загалом. Цінностями у просторі Академії мистецтв є глибока повага, любов, саможертовність, товариськість, емпатія.

Унікальність простору Академії $є$ беззаперечною й обгрунтованою героєм-художником: «На дворе сырая, гнилая осень, а в Академии нашей блистательная выставка» ${ }^{114}$. Проєкція мистецького діапазону Академії мистецтв настільки сутнісно впливова на весь простір континууму, що здатна затьмарити примару осінніх буднів міста. Психологічний простір наповнений рецепцією естетики творів образотворчого мистецтва.

Метафізичний часопростір - складніший, аніж вихід за межі свого «Я», це простір надсвідомості героя (виходячи з розуміння Е. Гуссерля, М. Мамардашвілі), що передує міметичному відтворенню матерії, розташуванню предметів середовища в часі. Метафізичний часопростір окреслює рівень опису та створення метамови - універсального слова,

${ }^{110}$ Шевченко Т. Повне зібрання творів : у 6-ти т. Київ : Наук. думка, 2003. Т. 4 Повісті. С. 141.

111 Там само.

112 Тодчук Н. Роман Івана Франка «Для домашнього огнища» : час і простір. Львів, 2002. С. 155.

${ }_{113}$ Шевченко Т. Повне зібрання творів : у 6-ти т. Київ : Наук. думка, 2003. Т. 4 : Повісті. С. 177.

114 Там само. С. 165. 
яке поєднує рівні сюжету, свідомості й набуває у творі загалом метамовного значення, бо пов'язане 3 ідейним осмисленням цілого тексту, зокрема простору й часу ${ }^{115}$. Герой-оповідач у цьому аспекті відтворення подій стає видимим у тому сенсі, що саме він установлює метамову опису середовища Академії та стоїть на перетині топографічного й психологічного часопросторів. Це відбувається завдяки згущенню, конкретизації прикмет часу та простору, де автороповідач перебуває над цими модусами в ретроспекції минулого, себто функціонуе у глибинах метафізичної рецепції. М. Мерло-Понті стверджує, що саме реципієнт надає простору сенсу й перетворює його на цілісне явище як універсальну можливість відношення і взаємодії речей у середовищі: «Ці відношення існують тільки завдяки суб’єкту, який їх описує і несе в собі» ${ }^{116}$.

Герой-оповідач у повісті «Художник» - частина Шевченкового задуму, тому він цілком підпорядковується авторському часопростору. Часто має місце маніпуляція із простором, гра із часопростором. Людина здатна за допомогою фантазії, уяви переселятися в інший простір - це підкорення реального буття завдяки розширенню свого внутрішнього простору ${ }^{117}$. Здавалося б, автор-оповідач давно покинув часопростір Академії мистецтв, коли залишив Північну Пальміру, проте бачимо, що він завдяки погляду «згори» ніби перебуває у стінах Академії, прогулюючись ii класами, тому існує в метафізичному часопросторі загалом зі своїми думками й емоціями, пов'язуючи сюжетний і психологічний рівні хронотопу.

\section{ВИСНОВКИ}

Топос ретранслює світ міста крізь структури людської свідомості й підсвідомості, де архітектурні та природні елементи пройняті антропологічними началами. Унікальність локусів міста полягає в тому, що вони охоплюють місце, час, психологію людської душі в один плин буття. Реалії історичних подій ретранслюються крізь топоси міста, що стають живими свідками різних епох у часі та просторі, уособлюючи міста як генератори онтологічно-історичного досвіду людства. Роздуми Т. Шевченка про історичне минуле, сучасну авторові дійсність, втілені у складну часопросторову композицію подій, набувають метафізичної глибини крізь культурну семіосферу топосів

115 Тороп П. Словарь терминологии тартуско-московской семиотической школы. URL: http://diction.chat.ru/xronotop.html (дата звернення: 15.04.2020).

${ }_{116}$ Мерло-Понти М. Феноменология восприятия. Санкт-Петербург : Ювента ; Наука, 1999. С. 313.

117 Копистянська Н. Час і простір у мистецтві слова. Львів : ПАІС, 2012. C. $88-89$. 
міст. Психологічний ракурс топосу розкриває сферу емотивних переживань, глибину внутрішнього єства героїв. Місто у творах створює собою категоріально інший простір - топос, де формуються моральні й матеріальні цінності, що стають запорукою розвитку аксіологічно-цивілізаційного поступу людства. Топос міста для Т. Шевченка постає в аспекті синхронії (зовнішній зміст міста) та в аспекті діахронії (сприйняття міста як історії народу, життя автора, як культурний палімпсест доби). Топос міста виступає як своєрідна схема в ментальному просторі автора, що відбиває суб'єктивно збудовані зв'язки між явищами предметної дійсності. Урбаністичний простір буття героїв спроєктовано в ракурсах дії, пам'яті, інтуїтивного пізнання реалій міста. Художні параметри відтворення топосу пов'язані із глибоким авторським розумінням духовної сутності, телеології місць, які породжують різноманітні асоціації, смисли. Цивілізаційні та природні локуси стають історичними універсаліями, місцями душевної рівноваги й повноти екзистенції буття, крізь які автор передає особистісні інтенції розуміння генези урбаністичного простору.

\section{АНОТАЦІЯ}

Дослідження репрезентує аспекти функціонування точкового, лінеарного, об’ємного топосу міста у творах Т. Шевченка. Окреслено теоретичні аспекти семіозису міського часопростору. Визначено художню генезу, синкретизм, знаки, символи, модуси відтворення топосу. Інтерпретовано семіотико-символічну структуру локусів, хронотопу, замкненого світу міста. Простежено проблемно-тематичний діапазон, з'ясовано специфіку авторської візії урбанізму, проаналізовано спосіб буття героїв. Просторовий континуум топосу міста розглянуто крізь антропологічний модус відтворення дійсності.

\section{ЛІТЕРАТУРА}

1. Анциферов Н. Пути изучения города как социального организма. Ленинград : Сеятель, 1926. $151 \mathrm{c}$.

2. Артеменко А. Онтологія топосу. Наукові записки Наџіонального університету «Острозька академія». Серія «Філософія». 2014. Вип. № 15. С. 84-85.

3. Ауэрбах Э. Мимесис. Изображение действительности в западноевропейской литературе. Москва : Прогресс, 1976. 556 с.

4. Барабаш Ю. «Коли забуду тебе, Срусалиме...» Гоголь і Шевченко. Порівняльно-типологічні студії. Харків : Акта, 2001. 375 с.

5. Бахтин М. Вопросы литературы и эстетики. Москва, 1975. 504 с.

6. Бергсон А. Творческая эволюция. Москва : ТЕРРА - Книжный клуб ; Канон-пресс-Ц, 2001. 384 с. 
7. Бердяев Н. Самопознание (опыт философской автобиографии). Москва : Книга, 1991. 446 с.

8. Богданова О. Топографічний образ міста у прозі М. Хвильового та романі «Берлін. Александерплатц» А. Дьобліна. Вісник Львівського національного університету ім. І. Франка. Серія «Іноземна філологія». 2014. Вип. 126. Ч. 1. С. 28-34.

9. Боронь О. Поетика простору у творчості Тараса Шевченка : монографія. Київ, 2005. 152 с.

10. Вирт Л. Урбанизм как образ жизни. Москва : Strelka Press, 2018. $180 \mathrm{c}$.

11. Вихор I. Дискурс міста в українській поезії кінця XIX - першої половини XX ст. : дис. ... канд. філол. наук: 10.01.06. Тернопіль, 2011. $258 \mathrm{c}$.

12. Гегель Г.В.Ф. Феноменология духа. Москва : Наука, 2000. 495 с.

13. Гетьман С. Просвітницький ідеал людини та його образна інтерпретація у повістях Т. Шевченка : автореф. дис. ... канд. філол. наук: 10.01.01. Київ, 2003. 19 с.

14. Гуссерль Э. Избранные работы / сост. В. Куренной. Москва : Издательский дом «Территория будущего», 2005. 464 с.

15. Демська-Будзуляк Л. Топос міста та літературний контекст раннього модернізму. Наукові праці Чорноморського державного університету ім. Петра Могили. Серія «Філологія». 2009. Т. 118. Вип. 105. С. 11-16.

16. Дзюба I. 3 криниці літ : у 3-х т. Київ : Вид. дім «КиєвоМогилянська академія», 2007. Т. 3 : Літературні портрети ; Дніпровський меридіан ; Зі спогадів. 893 с.

17. Доній Т. Архетипи і топоси постмодерністської поезії України та США : дис. ... канд. філол. наук: 10.01.05. Київ, 2018. 230 с.

18. Женетт Ж. Фигуры : в 2-х т. Москва, 1998. Т. 1. 472 с.

19.Задорожна Л. Історія літератури в критичних студіях М. Максимовича. "Я син свого народу». Наукова спадщина Михайла Максимовича (до 200-річчя з дня народження вченого). Київ : Просвіта, 2006. C. 50-60.

20. Карповець М. Місто як світ людського буття. Острог : Вид-во Нац. ун-ту «Острозька академія», 2014. 258 с.

21. Кирло Х. Словарь символов. Москва : ЗАО «Центрполиграф», $2010.525 \mathrm{c}$.

22. Клочек Г. Поетика візуальності Тараса Шевченка : монографія. Київ : Академвидав, 2013. 256 с.

23. Кодак М. Авторська свідомість і класична поетика. Київ : Фоліант, 2006. 336 с.

24. Копистянська Н. Час і простір у мистецтві слова. Львів : ПАІС, $2012.334 \mathrm{c}$. 
25. Курціус Е. Європейська література та латинське середньовіччя. Львів : Літопис, 2007. 752 с.

26. Левицький В. Наснага та моторошність «іного краю»: урбанізм у літературних творах Тараса Шевченка. Слово $і$ час. 2015. № 3. С. 28-36.

27. Лихачев Д. Поэтика древнерусской литературы. Москва, $1979.360 \mathrm{c}$.

28. Лотман Ю. Избранные статьи : в 3-х т. Таллин : Александра, 1992. T. $1.478 \mathrm{c}$.

29. Лотман Ю. Семиосфера. Санкт-Петербург : Искусство - СПБ, $2000.704 \mathrm{c}$.

30. Людина в есенційних та екзистенційних вимірах / відп. ред. В. Табачковський. Київ : Наук. думка, 2004. 245 с.

31. Мерло-Понти М. Феноменология восприятия. Санкт-Петербург, 1999. 603 с.

32. Новейший философский словарь / сост. и гл. науч. ред.: А. Грицанов. Минск, 2003. 1279 с.

33. Новик О. Історична ретроспектива в повісті Тараса Шевченка «Близнецы». Волинь - Житомирщина. 2010. № 21. С. 122-132.

34. Поліщук Я. Ревізії пам'яті : літературна критика. Луцьк : ПВД «Твердиня», 2011.216 с.

35. Тодчук Н. Роман Івана Франка «Для домашнього огнища»: час $\mathrm{i}$ простір. Львів : Від-ня Ін-ту л-ри ім. Т. Г. Шевченка, 2002. 204 с.

36. Топоров В. Миф. Ритуал. Символ. Образ: исследования в области мифопоэтического. Москва, 1995. 624 с.

37. Тороп П. Тотальний переклад. Вінниця : Нова книга, 2015. 264 с.

38. Тороп П. Хронотоп. Словарь терминологии тартускомосковской семиотической школы. URL: http://diction.chat.ru/ xronotop.html (дата звернення: 15.04.2020).

39. Туркина В. Город как «топос». Научные ведомости Белгородского государственного университета. Серия «Философия. Социология. Право». 2009. Вып. № 7. Т. 57. С. 73-79.

40. Фрейд 3. По ту сторону принципа наслаждения. Тотем и табу. «Я» и «Оно». Неудовлетворенность культурой. Харьков : Фолио, 2014. $480 \mathrm{c}$.

41. Хайдеггер М. Пролегомены к истории понятия времени. Томск : Водолей, 1998. 384 с.

42. Чхеайло А. Потенціал виживання людини в умовах песимістичних перспектив. Грані. 2012. № 1. С. 58-61.

43. Шевченко Т. Повне зібрання творів : у 6-ти т. Київ : Наук. думка, 2003. Т. 1 : Поезія 1837-1847. 784 с.

44. Шевченко Т. Повне зібрання творів : у 6-ти т. Київ : Наук. думка, 2003. Т. 2 : Поезія 1847-1861. 784 с. 
45. Шевченко Т. Повне зібрання творів : у 6 т. Київ : Наук. думка, 2003. Т. 3 : Драматичні твори. Повісті. 592 с.

46. Шевченко Т. Повне зібрання творів : у 6 т. Київ : Наук. думка, 2003. Т. 4 : Повісті. 600 с.

47. Шпенглер О. Закат Европы. Очерки морфологии мировой истории : в 2-х т. / ред. В. Матешук. Москва : Мысль, 1998. Т. 2. 606 с.

48. Элиаде М. Оккультизм, колдовство и моды в культуре. Киев : София ; Москва : ИД «Гелиос», 2002. 224 с.

49. Энциклопедия символов, знаков, эмблем. Москва : Эксмо ; Санкт-Петербург : Мидгард, 2007. 608 с.

50. Юнг К.Г. Душа и миф: шесть архетипов. Киев, 1996. 384 с.

51. Юнг К.Г. Подход к бессознательному. Человек и его символы / К.Г. Юнг и др. Санкт-Петербург : Б.С.К., 1996. С. 16-119.

52. Ярошевич I. Концепція творчої особистості в повістях Т. Шевченка. Науковий вісник Ужгородського університету. Серія «Філологія. Соиіальні комунікаиї̈». 2014. Вип. 1. С. 294-297.

53. Яффе А. Символы в изобразительном искусстве. Человек и его символы / К.Г. Юнг и др. Санкт-Петербург : Б.С.К., 1996. С. 298-377.

\section{Information about the author: Boklakh D. Yu.,}

Candidate for a Degree of the Department of Ukrainian Literature of the Faculty of Ukrainian Philology and Social Communications State Institution "Luhansk Taras Shevchenko National University" 1, Gogol Square, Starobilsk, Luhansk Region, 92703, Ukraine 